\title{
IDENTIFIKASI KERUSAKAN AREAL HUTAN MANGROVE AKIBAT AKTIVITAS PENDUDUK DI DAERAH AIRTIBA KABUPATEN KAIMANA
}

\section{(Damaging Area Identification of Mangrove Forest as $A$ Result of Antropogenic Activities in Airtiba, District of Kaimana)}

\author{
Novalinda Hanagrasia Konom ${ }^{1}$ Reinardus L. Cabuy ${ }^{1 凶}$ dan Alfredo O. Wanma ${ }^{1}$ \\ Jurusan Kehutanan, Fakultas Kehutanan Universitas Papua Manokwari, Papua Barat, \\ 98314. Tlp/Fax: +62986211065 . \\ $\square$ Penulis Korespondensi: Email: reinnardcabuy@gmail.com \\ Diterima: 30 Agust 2019| Disetujui: 24 Sep 2019
}

\begin{abstract}
Abstrak
Penelitian ini bertujuan untuk mengetahui aktivitas penduduk di sekitar areal hutan mangrove serta mengetahui luas kawasan mangrove yang telah rusak akibat aktivitas antropogenik di wilayah Airtiba, Kelurahan Krooy Kabupaten Kaimana. Metode yang digunakan dalam penelitian ini adalah metode deskriptif dengan teknik survei lapangan. Berdasarkan hasil penelitian diketahui terdapat enam indikasi penyebab kerusakan yaitu aktivitas penebangan untuk kayu bakar dan tambelo, perluasan areal permukiman, konversi lahan untuk tempat pengeringan ikan, tempat pembuangan sampah, perluasan tubuh air guna akses perahu dan area pertambakan di sekitar kawasan hutan mangrove Airtiba. Intensitas kerusakan terbesar disebabkan oleh aktivitas pertambakan sedangkan yang intensitas kerusakan terkecil disebabkan oleh aktivitas pembuangan sampah. Perhitungan IK menunjukkan kerusakan sebesar 8,60\% atau 20,31 ha dari total luas kawasan sebesar 236,13 ha yang mana masih dalam kategori intensitas kerusakan rendah.
\end{abstract}

Kata kunci: hutan mangrove, aktivitas atropogenik, intensitas kerusakan, Kaimana

\begin{abstract}
This study focuses on identifying damaging causing factors of mangrove forest area that primarily subjected to daily anthropogenic activities from inhabitant living around the forest. Descriptive method has been applied through semi-structural interview process in order to generate data. From the result standpoint, it has been found six potential indications that lead to damage from surrounding daily activities such as chopping down mangrove tree for firewood and tambelo, widening inhabitant area for living, conversion for fish drying management, landfill area, widening area that is intended for boat accessibility, and ponding area. It turned out that the most intense damaging factor was ponding activity, while the lowest intense damaging factor was waste dump activity. Damaging intensity was $8.60 \%$ or about 20.31 ha from the total area of 236.13 ha in which is still low.
\end{abstract}

Keywords: mangrove forest, anthropogenic activity, damaging intensity, Kaimana 


\section{PENDAHULUAN}

Hutan mangrove merupakan ekosistem yang berada pada wilayah intertidal, dimana pada wilayah tersebut terjadi interaksi yang kuat antara perairan laut, payau, sungai dan terestrial. Interaksi ini menjadikan ekosistem mangrove mempunyai tingkat keanekaragaman yang tinggi baik keanekaragaman flora maupun fauna. Keanekaragaman yang tinggi tersebut memberikan interaksi dan asosiasi antar berbagai organisme lain seperti fungi, mikroba, alga, mikro dan makro fauna, serta tumbuhan lainnya yang selanjutnya membentuk komunitas mangrove. Komunitas mangrove tersebut berinteraksi dengan faktor abiotik seperti iklim, udara, tanah, dan air yang membentuk ekosistem mangrove (Sengupta 2010).

Hasil analisis spasial oleh Giri dkk. (2011) mengemukakan bahwa total luas hutan mangrove di dunia mencapai 13.776.000 ha dimana Indonesia sebagai negara dengan hutan mangrove terbesar di dunia memiliki luasan sebesar 3,1 juta ha atau sekitar 22,6\%. Dari total luas hutan mangrove di Indonesia tersebut, dataran Papua menjadi kawasan mangrove terluas dengan luas mencapai 1,6 juta ha (Saputro dkk. 2009).

Hutan mangrove memiliki peranan yang penting di lingkungan pesisir. Terdapat tiga fungsi utama hutan mangrove yakni fungsi fisik dimana berperan sebagai penahan gangguan fisik seperti angin, ombak, penyaring bahan pencemar, pengendali banjir dan pencegah intrusi air laut ke daratan. Fungsi biologis yaitu sebagai kawasan pemijahan (spawning ground), kawasan asuhan (nursery ground), dan kawasan mencari makan (feeding ground) bagi ikan dan biota laut lainnya. Sementara fungsi ekonomi secara langsung memberikan kontribusi berupa kayu untuk bahan baku bangunan serta ekstraksi hutan mangrove untuk keperluan lainnya (Romimotarto 2001). Selain itu, fungsi tersebut juga strategis sebagai produsen primer yang mampu mendukung dan menstabilkan ekosistem laut maupun daratan (Hiariey 2009).

Dengan beragamnya fungsi dan manfaat hutan mangrove, secara langsung dan tidak langsung turut memberikan kontribusi bagi manusia dan mendukung kehidupan masyarakat di sekitar hutan mangrove tersebut. Namun disisi lain, pemanfaatan secara berlebihan oleh manusia dalam kurung waktu yang cukup lama akan merusak hutan mangrove dan ekosistemnya serta menurunkan kualitas daya dukung hutan mangrove bagi kehidupan disekitarnya. Sumber nuflah akan semakin berkurang dan mempengaruhi kehadiran ikan dan fauna perairan lain yang selama ini menjadi sumber protein untuk dikonsumsi. Selain itu, kerusakan hutan mangrove akan mengurangi fungsi fisik sebagai penyangga air laut dan ombak pasang terhadap wilayah pesisir dan pemukiman (Hartati dan Harudu 2016). Tujuan dilakukan penelitian ini ialah untuk mengetahui dampak aktivitas penduduk dan mengetahui luas kawasan mangrove yang telah rusak akibat aktivitas antropogenik di wilayah Airtiba, Kelurahan Krooy Kabupaten Kaimana.

\section{METODE PENELITIAN}

Penelitian ini dilakukan pada kawasan hutan mangrove Airtiba, Kelurahan Krooy Kabupaten Kaimana yang berlangsung selama kurang lebih 2 bulan, yaitu dari bulan Juni sampai dengan bulan Agustus tahun 2019. Metode yang 
digunakan dalam penelitian ini adalah metode deskriptif dengan teknik survei kawasan mangrove Airtiba dan interpretasi citra satelite.

\section{Varabel Pengamatan}

Variabel yang diamati dalam penelitian ini ada dua yaitu berupa aktivitas penduduk di sekitar kawasan mangrove yang berinteraksi langsung dengan hutan mangrove Airtiba dan pemerintah sebagai pengambil kebijakan pengembangan wilayah serta luas kawasan mangrove yang mengalami kerusakan akibat aktivitas antropogenik.

\section{Teknik Pengumpulan Data}

Data yang dikumpulkan dalam penelitian ini berupa data primer dan sekunder. Pengumpulan data primer dilakukan melalui wawancara semi struktural dengan alat bantu kuisioner (daftar pertanyaan) dengan penentuan responden sebanyak $15 \%$ dari total jumlah kepala keluarga sebesar 144 kepala keluarga, yang bermukim di sekitar kawasan hutan mangrove guna memperoleh informasi terkait aktivitas penduduk di sekitar areal hutan mangrove Airtiba. Selain itu, observasi lapangan secara langsung dengan melihat kegiatan penduduk terhadap pemanfaatan ekosistem di hutan mangrove. Untuk mengetahui intensitas kerusakan, pengambilan data berupa titik dan luas areal kerusakan dilakukan pada areal pengamatan secara keseluruhan yang terindikasi telah rusak. Sementara data sekunder berupa laporan dan program kerja akan diperoleh dari Dinas dan Instansi pemerintah daerah terkait terhadap kawasan hutan mangrove Airtiba.

\section{Pengolahan Data}

Semua data pengamatan berupa kuisioner yang diperoleh kemudian di input dalam bentuk tabel tematik (tabulating) dengan menggunakan program Microsoft Excel dan dilakukan kuantifikasi data guna melihat frekuensi interaksi penduduk disekitar dengan hutan mangrove Airtiba. Sedangkan data tracking dengan menggunakan alat GPS di lapangan terhadap kerusakan hutan mangrove kemudian dibuat dalam bentuk lay out peta dengan menggunakan software Arcgis.

Kerusakan mangrove yang diamati sepanjang jalur pengamatan dinyatakan dalam presentasi yang dihitung dengan membandingkan besar areal yang ditumbuhi mangrove dan areal yang tidak ditumbuhi tumbuhan, serta daerah yang bertambah dan berkurang luasnya. Pendekatan umum yang digunakan berdasarkan formula Arsyad (1999) dalam Rumakat (2013) adalah sebagai berikut:

$\mathrm{IK}(\%)=\frac{\text { luas areal terkonversi }}{\text { luas keseluruhan } \text { kawasan }} \times 100$

Dimana IK $=$ Intensitas kerusakan hutan

\section{Analisis Data}

Data yang diperoleh dianalisis secara deskriptif dan disajikan dalam bentuk tabel dan gambar atau peta.

\section{HASIL DAN PEMBAHASAN}

\section{Kondisi Umum Kawasan Mangrove} Airtiba

Total luas hutan mangrove di Kabupaten Kaimana mencapai 50.226,88 ha $(2,62 \%)$ dari total luas kawasan hutan sebesar 1.724.326 ha, dimana luas hutan mangrove untuk Distrik Kaimana Kota 
sendiri mencapai 6.345,044 ha (BPS 2016). Sedangkan untuk luas kawasan hutan mangrove Airtiba berdasarkan data Badan Perencanaan Pembangunan Daerah (BAPPEDA) tahun 2014 seluas 236,13 ha.

Komposisi dan struktur jenis hutan mangrove cukup bervariasi bergantung pada tingkat pelumpuran dan jangkauan pengaruh pasang surut air laut. Jumlah jenis tumbuhan mangrove yang dijumpai berkisar antara $6-15$ jenis dengan zonasi relatif jelas untuk tipe mangrove muara, yaitu Avicenia sp. dan Sonneratia sp. yang merupakan zonasi terluar selanjutnya ke arah dalam teluk diikuti oleh Rhizophora sp. dan Bruquiera sp. serta Nypha fruticans sp. dan Xylocarpus sp. Hampir seluruh tipe hutan mangrove di kawasan Kabupaten Kaimana terutama daerah estuari, didominasi oleh jenis mangrove Rhizophora spp., Bruquiera spp. dan Sonneratia sp., dengan kerapatan pohon berkisar antara 1000-1600 pohon per hektar, tipe ini termasuk jenis mangrove yang berada di kawasan Airtiba (RPIJM Kabupaten Kaimana 2010).

Berdasarkan data RPIJM Kabupaten Kaimana (2010) dikatakan bahwa kerapatan pohon mangrove berkisar antara $1000-1600$ pohon per hektar. Pada tipe vegetasi mangrove estuari yang rapat dan kompak umumnya menyebar di sekitar muara sungai besar atau di sepanjang teluk, kerapatan semai untuk semua jenis mencapai 10.000-40.000 semai/ha, sapihan mencapai 800-2400 sapihan/ha, tiang mencapai 300-700 pohon/ha dan tingkat pohon mencapai 65-135 pohon/ha. Beberapa hutan mangrove yang tersebar sporadik dengan lebar hanya mencapai 20 meter pada cekungan-cekungan pantai bersubstrat pasir berlumpur didominasi oleh Rhizopora spp.

Keadaan vegetasi mangrove Airtiba dapat dikatakan cukup baik dilihat dari pemanfaatan hutan oleh masyarakat setempat yang masih bersifat tradisional. Selain itu adapun kegiatan dari pemerintah berupa penanaman kembali mangrove di daerah yang telah terdegradasi.

Mangrove yang terindikasi tumbuh di kawasan Airtiba terdiri dari empat famili yaitu Rhizophoraceae, Rubiaceae, Meliaceae dan Sonneratiaceae yang terdiri dari sembilan jenis yaitu Bruguiera gymnorhiza, Ceriops decandra, Ceriops tagal, Rhizophora mucronata, Rhizophora apiculata, Schyphiphora hydrophyllacea, Xylocarpus granatum, Xylocarpus mollucensis dan Sonneratia alba.

Kemampuan beradaptasi dari tiap jenis mangrove terhadap keadaan lingkungan berbeda-beda. Hal ini mengakibatkan perbedaan komposisi hutan mangrove dengan batas-batas yang khas karena adanya pengaruh fisiologi seperti kondisi tanah, kadar garam, sedimentasi, lamanya pengenangan, energi gelombang dan arus pasang surut.

Pengaruh faktor fisiologis menyebabkan zonasi yang terjadi di dalam ekosistem mangrove. Zonasi terjadi akibat adanya kemampuan beradaptasi atau toleransi jenis tumbuhan mangrove tertentu terhadap kondisi lingkungannya. Zonasi jenis tumbuhan mangrove dapat dilihat sebagai bagian dari proses suksesi dan merupakan hasil reaksi ekosistem dengan kekuatan yang datang dari luar seperti tipe tanah, salinitas, tingginya genangan air dan pasang surut air laut (Rumakat 2013). Jenis dan komunitas mangrove pada 
kawasan hutan mangrove Airtiba adalah sebagai berikut :

Zonasi depan :

S. alba, Ceriops decandra dan Ceriops tagal.

Zonasi tengah :

$R$. mucronata, $R$. apiculata, dan Xylocarpus granatum

Zonasi belakang :

B. gymnorhiza, Xylocarpus mollucensis dan S. hydrophyllacea.

\section{Aktivitas Sosial Ekonomi Penduduk}

Masyarakat yang bermukim di sekitar kawasan hutan mangrove Airtiba Kelurahan Krooy Kabupaten Kaimana berasal dari dua rumpun masyarakat yaitu suku asli penduduk setempat dan pendatang. Suku asli yang mendiami kawasan hutan mangrove Airtiba adalah suku Mairasi dan Irarutu yang merupakan suku yang dominan pada daerah tersebut. Selain itu, terdapat suku pendatang asal Papua yang mendiami daerah Airtiba yaitu suku Kamoro, Biak dan Serui. Sedangkan untuk pendatang non papua ialah penduduk yang berasal dari luar Papua seperti suku Jawa, Bugis, Buton, Toraja, Key, Tanimbar dan Ambon. Berdasarkan data survey di lapangan, jumlah penduduk yang mendiami kawasan terdiri atas 644 Jiwa, dengan jumlah kepala keluarga (KK) sebanyak 144.

Umumnya, masyarakat di daerah Airtiba berprofesi sebagai nelayan, petani dan buruh, namun ada juga yang bekerja sebagai pegawai negeri sipil (PNS) maupun pedagang. Untuk memenuhi kebutuhan pangan sehari-hari, penduduk Airtiba memanfaatkan hasil laut yang berada disekitar hutan mangrove. Pemanfaatan hasil laut di kawasan ini sering dilakukan oleh masyarakat yang berprofesi sebagai nelayan, petani dan buruh. Biota laut yang dapat dijadikan sumber pangan yaitu jenis ikan, kepiting, udang dan beberapa jenis kerangkerangan. Hasil tangkapan berupa biotabiota laut di sekitar kawasan ini lebih dari cukup untuk memenuhi kebutuhan pangan mereka. Selain untuk memenuhi pangan, hasil tangkapan yang diperoleh jika dirasa lebih, biasanya penduduk menjualnya di pasar yang berada di dekat kawasan hutan mangrove Airtiba. Hasil tangkapan berupa ikan dijual pertali yang berisi 6 sampai 8 ekor setiap talinya dengan harga yang berkisar antara Rp. $10.000,00$ - Rp. 20.000,00. Hasil dari penjualan tersebut selanjutnya digunakan untuk memenuhi kebutuhan mereka yang lainnya.

Semakin besar penduduk yang bermukim di kawasan hutan mangrove maka semakin besar tingkat kerusakan yang terjadi serta berkurangnya luas kawasan yang diakibatkan oleh aktivitas manusia. Kondisi sosial dan ekonomi penduduk di sekitar kawasan hutan mangrove sangat berpengaruh terhadap pertumbuhan ekosistem mangrove.

Adanya ketergantungan kehidupan masyarakat pantai terhadap hutan mangrove, dikarenakan hutan mangrove dapat menyediakan kayu bangunan, kayu bakar, tempat mencari ikan, kepiting, udang maupun tempat usaha pertambakan sebagai sumber nafkah mereka. Terkait dengan kondisi tersebut, kegiatan masyarakat pantai pada akhirnya akan memanfaatkan hutan mangrove secara tidak ramah lingkungan, dan dampaknya hutan mangrove akan terdegradasi dan rusak, bahkan sumber daya alam tersebut akan punah. Sebenarnya, masyarakat pantai sudah mengetahui tentang peran dan manfaat hutan mangrove terhadap 
lingkungannya, tetapi mereka tidak ada pilihan lain karena untuk mempertahankan kehidupan mereka bersama keluarganya harus memanfaatkan hutan tersebut (Pramudji 2000).

\section{Bentuk Pemanfaatan Hutan Mangrove}

Pemanfaatan hutan mangrove oleh masyarakat di kawasan mangrove Airtiba telah dilakukan sejak lama, umumnya masyarakat memanfaatkan hutan mangrove untuk keperluan kayu bakar dan bahan baku pengobatan secara tradisional. Selain itu adapun hasil lainnya di sekitar hutan mangrove yang dapat dimanfaatkan untuk menunjang kehidupan masyarakat di kawasan ini yaitu berupa hasil tangkapan ikan, udang, kepiting, dan beberapa jenis kerangkerangan.

\section{Pemanfaatan Kayu Bakar \\ Pemanfaatan mangrove yang} dilakukan oleh masyarakat di kawasan Airtiba diantaranya ialah pemanfaatan kayu bakar. Sebagian besar masyarakat yang memanfaatkan kayu mangrove sebagai kayu bakar ialah penduduk asli setempat yang berprofesi sebagai petani dan buruh. Jenis-jenis pohon mangrove yang umumnya dimanfaatkan sebagai kayu bakar adalah Rhizophora mucronata, Rhizophora apiculata dan Bruguiera gymnorrhiza. Berdasarkan hasil pengamatan di lapangan jenis yang dominan di kawasan ini adalah Rhizophora mucronata dan Bruguiera gymnorrhiza. Sehingga, jenis-jenis mangrove ini sering dimanfaatkan sebagai kayu bakar. Selain itu, karena sifatnya yang mudah terbakar dan mudah diperoleh oleh masyarakat setempat.

Sejalan dengan itu, Pariyono (2006) menyebutkan bahwa kayu bakar sebagai sumber energi untuk kebutuhan memasak dirasakan besar manfaatnya karena dapat diperoleh dengan mudah dengan harga yang tidak mahal. Jenis mangrove yang biasanya di manfaatkan sebagai kayu bakar ialah jenis yang berasal dari famili Rhizophoraceae seperti Rhizopora apiculata, Rhizopora mucronata, dan Bruguiera gymnorrhiza (Inoue dkk. 1999).

Pengambilan kayu bakar dilakukan sebanyak 3 sampai 5 kali dalam seminggu sesuai dengan kebutuhan. Masyarakat biasanya menebang pohon mangrove yang kemudian dibelah menjadi bagianbagian kecil yang dijadikan kayu bakar sebagai sumber energi untuk memasak. Selain itu sebagiannya akan dijual di sekitar tempat tingal mereka. Kayu bakar yang dijual berisi 20 sampai 30 belahan kayu yang diikat menjadi 1 ikatan, dijual dengan harga Rp 20.000,00 per tumpuk.

\section{Bahan Obat-Obatan}

Masyarakat di daerah Airtiba memanfaatkan bagian dari tumbuhan mangrove yang terdapat tambelo sebagai bahan baku pengobatan secara tradisional. Tambelo adalah jenis mollusca yang berbentuk seperti cacing berwarna putih yang hidup di dalam batang-batang pohon mangrove. Tambelo sering dikomsumsi oleh masyarakat suku Kamoro untuk mengobati penyakit yang mereka rasakan seperti diare, sakit kepala, rematik, dan pegal-pegal pada tubuh. Selain itu, tambelo juga dipercaya oleh mereka mempunyai nilai gizi yang tinggi untuk memberikan stamina pada saat bekerja. Secara ekologi, tambelo menyukai kayu yang sudah mati atau hampir lapuk. Oleh karena itu dengan pengetahuan tradisional, masyarakat suku kamoro menebang kayu mangrove dan membiarkannya menjadi lapuk untuk 
menghadirkan tambelo pada kayu tersebut. Frekuensi penebangan kayu mangrove yang terdapat tambelo dilakukan hampir setiap hari.

\section{Perluasan Areal Permukiman}

Seirama dengan meningkatnya populasi beberapa tahun terakhir ini, serta pesatnya pembangunan di berbagai propinsi, maka kebutuhan akan tempat tinggal juga bertambah. Namun dengan terbatasnya tanah untuk pemukiman khususnya di wilayah yang berpenduduk padat, maka masyarakat cenderung untuk melirik hutan mangrove dan kemudian terpaksa digunakan untuk mendirikan rumah (Pramudji 2000). Kawasan mangrove Airtiba tidak terlepas dari pembangunan pada daerah tersebut, hal ini dikarenakan terbatasnya tanah dan permukiman serta kawasan ini berdekatan dengan lokasi perdagangan (pasar), sehingga masyarakat cenderung memanfaatkan lahan mangrove untuk dijadikan perluasan areal permukiman atau perumahan. Hasil dari pembangunan pada areal ini akan menyebabkan penurunan kualitas lingkungan yaitu ekosistem mangrove.

Pembukaan Hutan Mangrove Guna Akses Perahu

Sebagai tempat yang menghasilkan nilai ekonomi bagi para nelayan di sekitar kawasan hutan mangrove Airtiba, menyebabkan penduduk pada daerah ini dengan tingkat kepemilikan perahu yang tinggi. Hal ini disebabkan kawasan mangrove yang merupakan feeding ground atau tempat mencari makan bagi ikan dan biota laut lainnya serta lokasinya yang berbatasan langsung dengan laut lepas dimana selain mendapatkan ikan di kawasan mangrove para nelayan juga dapat menjadikan kawasan mangrove sebagai tempat berlabuhnya perahu atau kapal-kapal mereka.

Untuk dijadikan tempat berlabuh perahu dan kapal-kapal kecil, penduduk di kawasan mangrove Airtiba melakukan penebangan dan penggalian pada kawasan ini untuk digunakan sebagai jalan masuk perahu dan kapal. Sehingga kapal atau perahu nelayan dapat berlabuh di sekitar perumahan penduduk yang merupakan pemilik perahu atau kapal tersebut. Jalan masuk perahu yang dibuat disesuaikan dengan ukuran perahu atau kapal yang akan masuk. Lebar jalan masuk untuk perahu kecil berkisar 3 sampai 5 meter, sedangkan lebar untuk perahu yang berukuran lebih besar dapat mencapai 10 sampai 15 meter.

\section{Konversi Mangrove Untuk Lahan Pertambakan}

Kecenderungan penurunan luas kawasan mangrove mengindikasikan bahwa terjadi degradasi hutan mangrove yang cukup nyata. Penyebab degradasi hutan diantaranya yaitu konversi lahan mangrove menjadi areal pertambakan. Wilayah pesisir Kabupaten Kaimana, dikenal sebagai kawasan yang mempunyai potensi perikanan yang cukup besar. Dibalik potensi yang besar terjadi kecenderungan penurunan produksi, yang menyebabkan masyarakat umumnya membudidayakan ikan di suatu tambak. Tambak umumnya dibangun di kawasan interdial mangrove, seperti tambak yang berada di kawasan mangrove Airtiba. Seperti yang diketahui, budidaya tambak berperan dalam peningkatan keuntungan dan pendapatan tetapi dapat juga menimbulkan kerusakan terhadap ekosistem mangrove. 


\section{Tempat Pengeringan Ikan}

Kegiatan pengeringan ikan oleh masyarakat nelayan di wilayah pesisir sudah dilakukan sejak lama. Masyarakat di kawasan mangrove Airtiba juga memanfaatkan lahan dari mangrove untuk dijadikan tempat pengeringan ikan. Pengeringan ikan yang dilakukan oleh masyarakat di daerah ini masih bersifat alami, dimana mereka menjemur ikan diatas rak-rak dan diletakan langsung dibawah sinar matahari. Proses pengeringan ikan bergantung pada sinar matahari, sehingga umumnya masyarakat melakukan penebangan pada areal mangrove dan mengkonversikan lahannya menjadi tempat pengeringan ikan.

\section{Tempat Pembuangan Sampah}

Kondisi ekosistem mangrove Airtiba merupakan lokasi ideal yang berdekatan langsung dengan permukiman penduduk dan pusat perdagangan (pasar) di Kabupaten Kaimana, mengakibatkan areal ini pada beberapa titik digunakan sebagai tempat pembuangan sampah. Limbah-limbah rumah tangga maupun limbah plastik sering dijumpai di muara sungai kawasan mangrove Airtiba.

Pradmuji (2000) menambahkan, kegiatan pembuangan limbah pertanian, agro-industri dan limbah rumah tangga baik itu yang langsung ke hutan mangrove maupun lewat sungai, juga akan menimbulkan berbagai masalah terhadap eksistensi hutan mangrove. Berbagai limbah yang dibuang ke areal hutan mangrove tersebut, akan menurunkan kualitas lingkungan perairan, sehingga pada akhirnya kehidupan biota akuatik akan terganggu. Limbah dan industri yang menggunakan senyawasenyawa organik dan anorganik yang dibuang di sekitar perairan hutan mangrove, juga menyebabkan tumbuhan mangrove akan menggugurkan daunnya dan kemudian mati.

\section{Intensitas Kerusakan Hutan Mangrove Airtiba}

Interaksi antara penduduk Airtiba dengan hutan mangrove dapat dilihat dari besarnya ketergantungan masyarakat terhadap hutan mangrove. Berdasarkan data yang diambil di lapangan, diketahui hampir setiap hari penduduk yang berada pada kawasan ini berinteraksi dengan hutan mangrove. Hal ini dikarenakan hutan mangrove memberikan banyak manfaat bagi masyarakat, sehingga untuk memenuhi kebutuhan hidup mereka sehari-hari masyarakat menggantungkan hidup mereka pada hutan mangrove.

Kegiatan masyarakat pantai pada prinsipnya selalu memanfaatkan sumber daya alam di sekitarnya seperti hutan mangrove yang memberikan banyak manfaat bagi kehidupan masyarakat setempat. Namun pada akhirnya mereka akan memanfaatkan hutan mangrove secara tidak ramah lingkungan, dan dampaknya hutan mangrove akan terdegradasi dan rusak, bahkan sumber daya alam tersebut akan punah. Sebenarnya, masyarakat pantai sudah mengetahui tentang peran dan manfaat hutan mangrove terhadap lingkungannya, tetapi mereka tidak ada pilihan lain karena untuk mempertahankan kehidupan mereka bersama keluarganya harus memanfaatkan hutan tersebut (Pramudji 2000).

Ketergantungan masyarakat terhadap kawasan hutan mangrove Airtiba mengakibatkan eksploitasi yang berlebihan, diantaranya eksploitasi untuk keperluan kayu bakar, sebagai bahan obat maupun yang diperuntukan sebagai pertambakan dan perluasan permukiman 
yang pada akhirnya mempunyai dampak negatif terhadap sumber daya alam tersebut. Terdapat 6 indikasi penyebab areal mangrove terbuka atau mengalami kerusakan berdasarkan perhitungan intesintas kerusakan (IK) yang dijabarkan dalam bentuk tabel di bawah ini.

Tabel 1. Jenis dan Intensitas kerusakan areal hutan mangrove Airtiba

\begin{tabular}{clcc}
\hline No. & \multicolumn{1}{c}{ Jenis kerusakan } & $\begin{array}{c}\text { Luas } \\
(\mathrm{ha})\end{array}$ & $\begin{array}{c}\text { IK } \\
(\%)\end{array}$ \\
\hline 1. & Pemanfaatan kayu bakar dan obat & 2,7 & 1,14 \\
2. & Perluasan permukiman & 3,1 & 1,31 \\
3. & Aksesibilitas jalan & 0,9 & 0,37 \\
4. & Tambak & 13,4 & 5,69 \\
5. & Tempat pengeringan ikan & 0,2 & 0,07 \\
6. & Pembuangan sampah & 0,04 & 0,02 \\
\multicolumn{7}{r}{} & Luas areal mangrove & 236,13 & 8,60 \\
\hline
\end{tabular}

Sumber data primer, 2019

Tabel 1 menunjukkan intensitas kerusakan yang berbeda-beda untuk setiap jenis kerusakan yang disebabkan oleh manusia, total intensitas kerusakan mangrove terbesar yaitu konversi lahan untuk pertambakan sebesar 5,69\% sedangkan intensitas kerusakan terkecil ialah jenis kerusakan yang disebabkan oleh aktivitas pembuangan sampah yaitu $0,02 \%$ atau 0,04 ha dari kerusakan yang ada di kawasan hutan mangrove Airtiba. Jenis dan intensitas kerusakan areal hutan mangrove dapat dilihat pada gambar grafik 1.

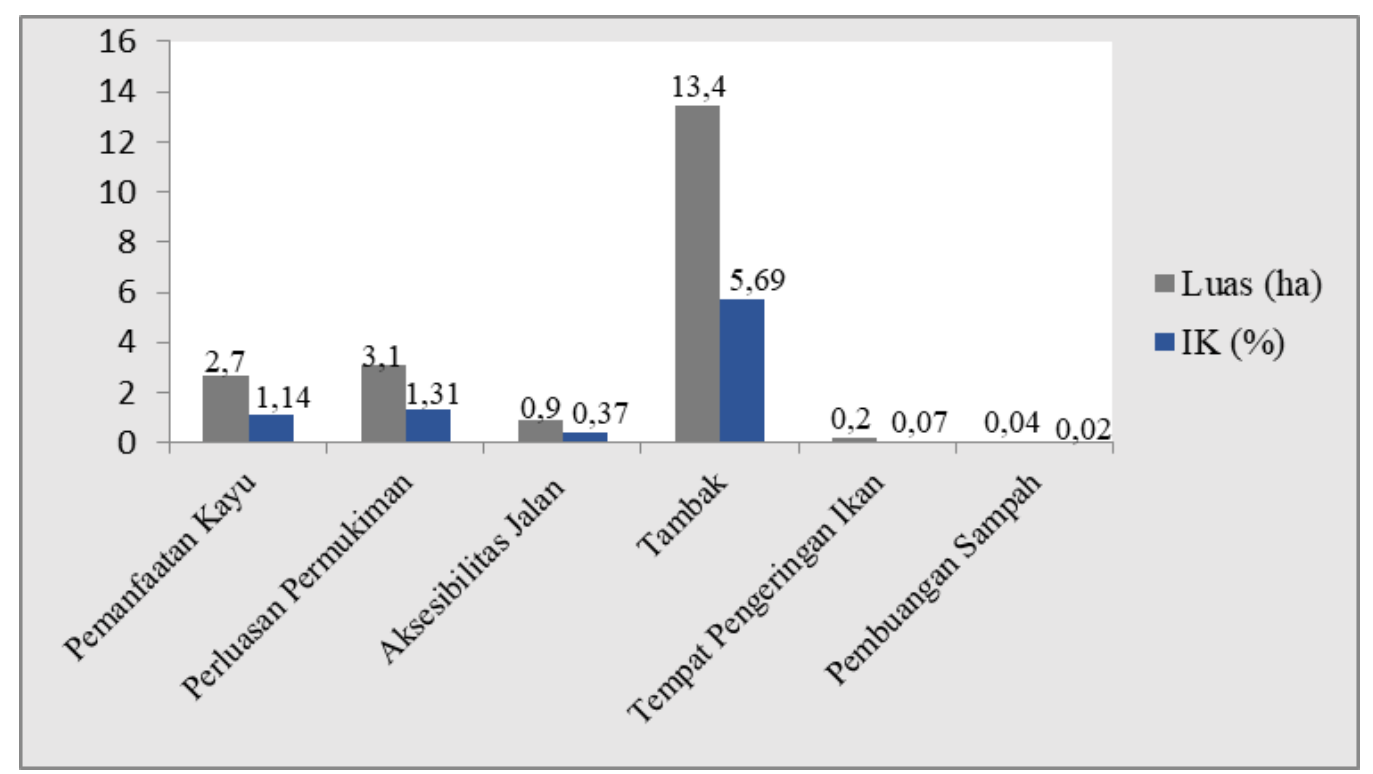

Gambar 1. Jenis dan intensitas kerusakan areal hutan mangrove Airtiba 


\section{Kriteria Kerusakan Hutan Mangrove}

Kriteria baku kerusakan hutan mangrove ditetapkan berdasarkan persentase luas tutupan dan kerapatan mangrove yang hidup dalam suatu luasan tertentu, sebagaimana yang diatur dalam Peraturan Menteri Lingkungan Hidup Nomor 201 Tahun 2004.

Tabel 2. Kriteria baku kerusakan hutan mangrove

\begin{tabular}{clcc}
\hline Kriteria & $\begin{array}{c}\text { Penutupan } \\
(\%)\end{array}$ & $\begin{array}{c}\text { Kerapatan } \\
\text { (pohon/ha) }\end{array}$ \\
\hline \multirow{2}{*}{ Baik } & Sangat padat & $\geq 75$ & $\geq 1500$ \\
& Sedang & $\geq 50-<75$ & $\geq 1000-<1500$ \\
\hline Rusak & Jarang & $<50$ & $<1000$ \\
\hline
\end{tabular}

Sumber: Keputusan Menteri Lingkungan Hidup No. 201, 2004

Berdasarkan data yang diambil di lapangan, kerusakan mangrove Airtiba yang terjadi didominasi oleh dampak aktivitas manusia. Data yang dikumpulkan berupa jenis dan luas kerusakan serta persentase penggunaan lahan, digunakan untuk dapat mengetahui tingkat kerusakan. Spot areal kerusakan hutan mangrove Airtiba dibuat dalam bentuk, peta guna mengetahui titik atau lokasi areal yang sudah terbuka atau rusak, seperti pada gambar berikut.

Berdasarkan gambar peta dan hasil pengamatan langsung di lapangan diketahui terdapat 28 spot areal hutan mangrove yang rusak atau terbuka dengan jenis dan bentuk kerusakan yang berbedabeda. Luasan hutan mangrove Airtiba berkurang 20,31 ha dengan intensitas kerusakan sebesar $8,60 \%$ dari total luas kawasan hutan mangrove Airtiba yaitu 236,13 ha yang terjadi penurunan luas kawasan menjadi 215,82 ha di tahun 2019. Dimana dari total penutupan lahan ini menunjukkan $91,40 \%$ penutupan lahan mangrove Airtiba masih cukup baik.

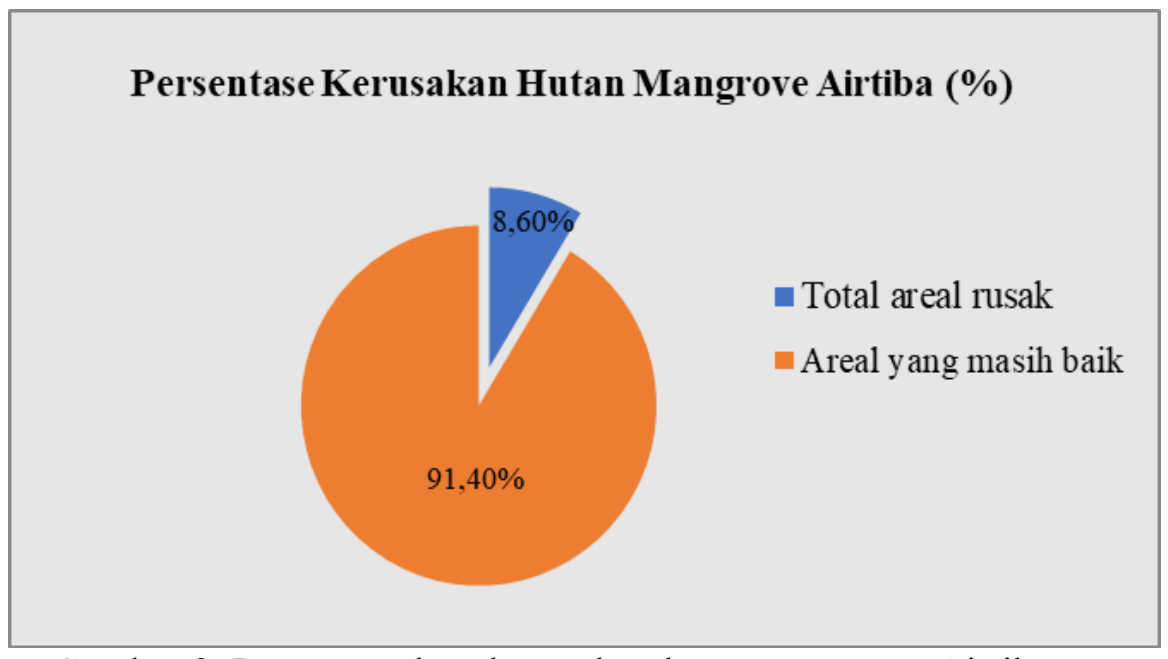

Gambar 2. Persentase luas kerusakan hutan mangrove Airtiba 
Data hasil analisis penelitian diketahui tutupan lahan hutan mangrove Airtiba tersisa 91,4\% dengan kerapatan pohon berkisar antara 1000-1600 pohon per hektar (RPIJM Kabupaten Kaimana, 2010). Berdasarkan data ini, ditentukan kriteria baku kerusakan hutan mangrove (tabel 2) sehingga dapat dikatakan hutan mangrove Airtiba termasuk dalam kriteria baik dengan kerapatan yang padat.

\section{DAFTAR PUSTAKA}

Badan Perencanaan Pembangunan Daerah (BAPPEDA). 2014. Data wilayah Kabupaten Kaimana tahun 2014.

Badan Pusat Statistik (BPS). 2016. Kabupaten Kaimana dalam angka. Badan Pusat Statistik Kabupaten Kaimana.

Giri C, O chieng, Tieszen LL, Zhu Z, A Singh, T Loveland, J Masek and Duke N. 2011. Status and distribution of mangrove forests of the world using earth observation satellite data. Global Ecology and Biogeography, 20 (1): 154-159.

Hartati dan Harudu L. 2016. Identifikasi jenis-jenis kerusakan ekosistem hutan mangrove akibat aktivitas manusia di Kelurahan Lowu-Lowu, KecamatanLea-Lea, Kota Baubau. Jurnal Penelitian Pendidikan Geografi, Vol 1 (1): 30-45.

Hiariey SL. 2009. Identifikasi nilai ekonomi ekosistem hutan mangrove di Desa Tawiri Ambon. Jurnal Organisasi dan Manajemen, Vol 5 (1): 23-34.

Inoue Y, Hadiyati O, Affendi HMA, Sudarma KR dan Budiana IN. 1999. Model pengelolaan hutan mangrove lestari. Hasil Studi Kelayakan di Republik Indonesia. Departemen Kehutanan dan Perkebunan Republik Indonesia, Denpasar.

Pariyono. 2006. Kajian potensi kawasan mangrove dalam kaitannya dengan pengelolaan wilayah pantai di Desa Panggung, Bulakbaru, Tanggultlare, Kabupaten Jepara. [Tesis] Program Pascasarjana Universitas Diponegoro, Semarang.

http://eprints.undip.ac.id/18674/1/Pari yono.pdf.

Pramudji. 2001. Ekosistem hutan mangrove dan peranannya sebagai habitat berbagai fauna aquatik. Jurnal Oseana, Vol 26 (4): 13-23.

Rencana Program Investasi Jangka Panjang (RPIJM). 2010. Gambaran umum Kabupaten Kaimana.

Romimotarto K. 2001. Biologi laut: Ilmu pengetahuan tentang biota laut. Jakarta: Penerbit Djambatan.

Rumakat DA. 2013. Tingkat kerusakan hutan mangrove di Distrik Oransbari Kabupaten Manokwari. [Skripsi]: Jurusan Kehutanan Fakultas Kehutanan Universitas Papua Manokwari. (Tidak diterbitkan).

Saputro GB, S Hartini, S Sukardjo, Al Susanto dan A Poniman. 2009. Peta mangroves Indonesia. Pusat Survei Sumber Daya Alam Laut, Badan Koordinasi Survei dan Pemetaan Nasional (BAKOSURTANAL), 329 hlm.

Sengupta R. 2010. Mangrove soldiers of our coasts. Mangrove for the future India, 20, Anand Lok, August Kranti Marg. India. 